\title{
The first evidence of subgroup IB isolates of Cucumber mosaic virus in Ukraine
}

\author{
T. P. Shevchenko, O. V. Tymchyshyn, E. AlDalain, \\ A. S. Bysov, I. G. Budzanivska, O. V. Shevchenko, V. P. Polishchuk \\ Educational and Scientific Center «Institute of Biology», \\ Taras Shevchenko National University of Kyiv \\ 64/13, Volodymyrska Str., Kyiv, Ukraine, 01601 \\ tyvonchuk@ukr.net
}

\begin{abstract}
Aim. In current work, we proceeded with the strain attribution of Ukrainian isolates CMV based on the phylogenetic analysis of the partial sequences of the coat protein gene. Methods. ELISA, RT-PCR, DNA sequencing and phylogenetic analysis. Results. Cucumber mosaic virus (CMV) is widespread among the variety of crops from the Cucurbitaceae and Solanaceae families in Ukraine. The symptomatic samples from different regions of Ukraine were collected and tested for the presence of CMV. The coat protein $(\mathrm{CP})$ gene of two isolates was amplified and sequenced. The partial nucleotide sequences of CP gene were determined and compared to those of other CMV strains belonging to the IA, IB and II subgroups. Comparison of the nucleotide sequences of Ukrainian isolates showed their similar identity percentages and close relationships with the subgroup IB strains from other countries. The highest nucleotide homology was shared with the strains ABI (Korea) and SD (China). Conclusions. Based on the highest identities of the coat protein gene sequences and close phylogenetic relationships with the subgroup IB members of CMV, the Ukrainian isolates under study were identified as belonging to the subgroup IB. Our findings show for the first time an occurrence of the IB subgroup isolates of CMV in Ukraine.
\end{abstract}

Keyw ord s: Cucumber mosaic virus, coat protein gene, phylogenetic analysis.

\section{Introduction}

Cucumber mosaic virus (CMV) is a type species from the genus Cucumovirus, family Bromoviridae. It is distributed worldwide in temperate and tropical areas causing epidemics in a variety of economically important crops. CMV is able to infect approximately 1300 species of more than 500 mono- and dicotyledonous plant genera among over 100 families, with new hosts reported every year [1]. Wide dissemination of CMV suggests its success in rapid adapting to new hosts and new environments [2].

The genome of CMV is a single-stranded, positivesense RNA. There are three RNA segments containing five open reading frames (ORF), which code for the proteins 1a, 2a, 2b, 3a, and coat protein (CP) [3].
RNAs 1 and 2 encode the components of the viral polymerase complex (1a and 2a). RNA 2 also encodes a protein functioning as a suppressor of the posttranscriptional gene silencing (2b) [4]. RNA 3 contains the $3 \mathrm{a}$ and coat protein genes separated by an intergenic region. Both of these genes are necessary for cell-to-cell movement of the virus in the host plant [3]. The 3a protein corresponds to the movement protein (MP). The coat protein is expressed from a subgenomic RNA (RNA 4) and plays an important role in aphid transmission and symptom expression $[5,6]$.

According to serological relationships, peptide mapping of the coat protein, nucleic acid hybridization and nucleotide sequence identity, a number of CMV isolates have been described previously and classified into two subgroups, designated I and II

(C) 2015 T. P. Shevchenko et al.; Published by the Institute of Molecular Biology and Genetics, NAS of Ukraine on behalf of Biopolymers and Cell. This is an Open Access article distributed under the terms of the Creative Commons Attribution License (http://creativecommons.org/licenses/by/4.0/), which permits unrestricted reuse, distribution, and reproduction in any medium, provided the original work is properly cited 

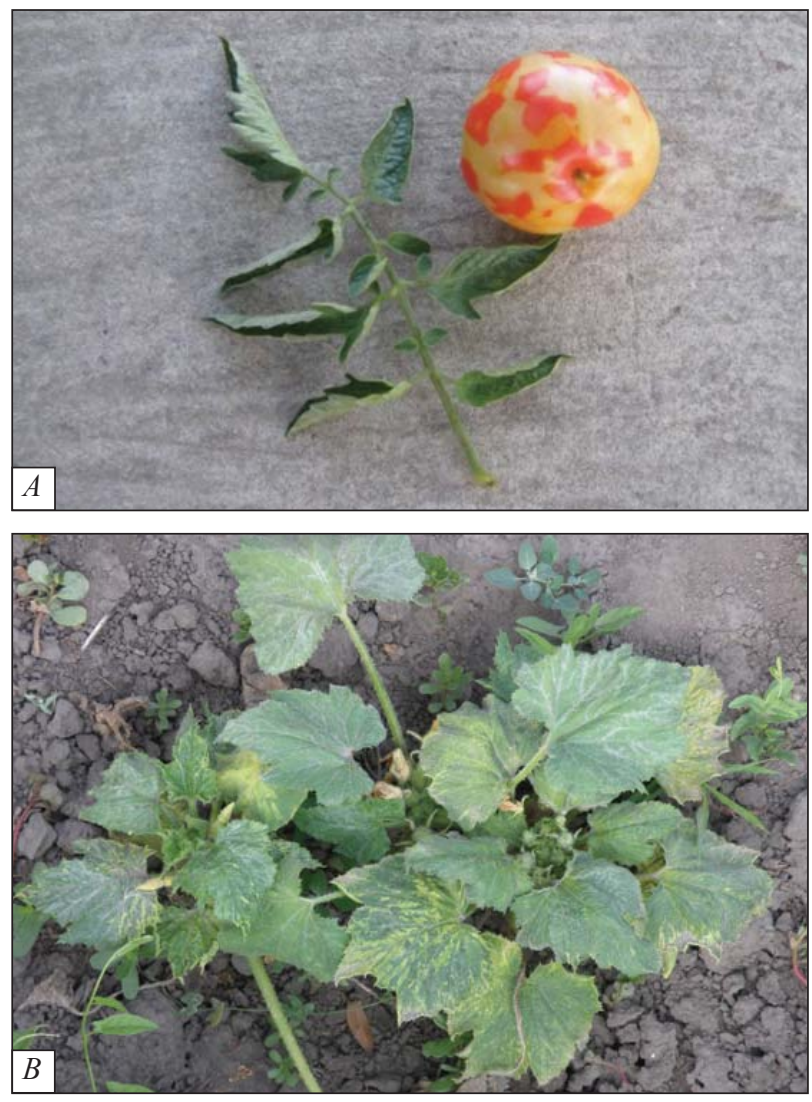

Fig. 1. Viral disease symptoms on plants under field conditions induced by Cucumber mosaic virus: $A$ ) discoloration of tomato fruit; $B$ ) dark green mosaic of leaf blade on squash

[7]. The development of phylogenetic analysis methods led to the further subdivision of CMV isolates of subgroup I into subgroups IA and IB [2]. The phylogeny estimations with full CP ORF, as well as the rearrangements in the 5 , nontranslated region of RNA 3 verified these designations [8].

The strains belonging to subgroups I and II have dissimilar characteristics. The CMV strains of subgroup I are considered more virulent than those of subgroup II. The members of subgroup IA occur all over the world. Contrarily, most isolates in subgroup IB are reported from East Asia, which is considered to be the origin of this subgroup [9]. The strains and isolates detected in other areas (the Mediterranean region, California, Brazil, Australia) have been introduced recently from Asia [1]. The mild strains belong to subgroup II; they are widespread in cooler areas of temperate regions, in the USA, Australia, and Africa [1].

Previously, CMV of subgroup II has been detected in infected pumpkin plants from Ukraine [10]. The subgroup attribution has been established based on the RT-PCR product size. However, the sequences of these isolates have not been obtained and their comparison with other known strains and isolates has not been performed. In current work, we proceeded with the strain attribution of Ukrainian isolates based on phylogenetic analysis of the partial sequences of the coat protein gene.

\section{Materials and Methods}

Plant samples were collected from different regions of Ukraine. The symptomatic samples were screened for the presence of viral antigens. Double-antibody sandwich enzyme linked immunosorbent assay (DASELISA) was conducted using commercial test-system of Loewe (Germany). Plant material was homogenized in $0.1 \mathrm{M}$ phosphate buffered saline (PBS), $\mathrm{pH}$ 7.4, 1:2 (m/v). Plant components were removed by centrifugation at $5.000 \mathrm{~g}$ for $20 \mathrm{~min}$ at $+4{ }^{\circ} \mathrm{C}$ using centrifuge PC-6. The supernatant was taken for further ELISA. DAS-ELISA was performed according to the manufacturer's recommendations. The results were checked at the wavelength of $405 / 630 \mathrm{~nm}$ using microplate reader Termo Labsystems Opsis MR (USA) with software Dynex Revelation Quicklink [11].

Total RNA was extracted from naturally infected plant samples using RNeasy Plant Mini kit (Qiagen, UK). The results were confirmed by electrophoresis of nucleic acids in $1.5 \%$ agarose gel. The two-step reverse transcription reaction (RT-PCR) was accomplished using two specific primers complementary to coat protein gene of CMV producing the amplicon with expected size of $500 \mathrm{bp}$ [12]: forward primer 5' TATGATAAGAAGCTTG TTTCGCGCA-3'; reverse primer - 5' TTTTAG CCGTAAGCTGGATGG ACAACCC-3'.

The first strand cDNA synthesis was performed at $42{ }^{\circ} \mathrm{C}$ for 60 min using Termo Scientific RevertAid Reverse Transcriptase according to the manufacturer's instructions. The first cycle was carried out at 95 ${ }^{\circ} \mathrm{C}$ for $1 \mathrm{~min}$. PCR was conducted for 30 cycles us- 


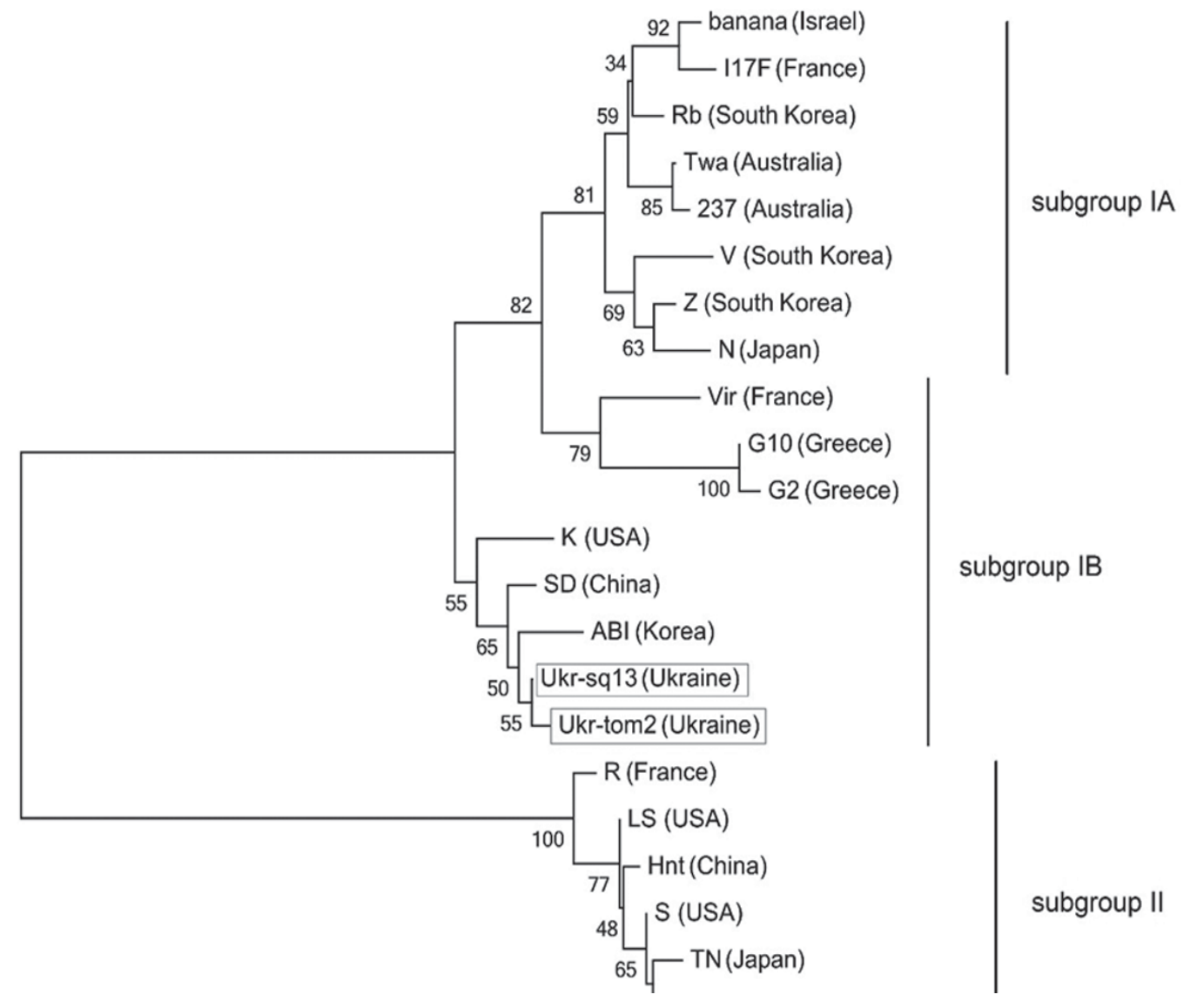

Fig. 2. Phylogenetic tree based on partial coat protein gene sequence of selected strains and Ukrainian isolates. Bootstrap values are shown above branches

ing the following parameters: $30 \mathrm{~s}$ at $95^{\circ} \mathrm{C}, 30 \mathrm{~s}$ at $56{ }^{\circ} \mathrm{C}, 1 \mathrm{~min}$ at $72{ }^{\circ} \mathrm{C}$, and then $5 \mathrm{~min}$ at $72{ }^{\circ} \mathrm{C}$ in the final cycles. PCR amplification was assessed by electrophoresis in a $1.5 \%$ agarose gel in TBE buffer ( 89 $\mathrm{mM}$ TRIS borate and $2 \mathrm{mM}$ EDTA, $\mathrm{pH}$ 8.3) and stained in ethidium bromide. The purified amplicons were sequenced using Applied Biosystems 3730x1 DNA Analyzer with Big Dye terminators, version 3.1 (Applied Biosystems, USA).

The aligned sequences of the part of coat protein gene of two CMV isolates were compared with the published sequences of CMV strains belonging to different subgroups available in the GenBank database using NCBI/ BLAST (http://www.ncbi.nlm.nih. gov/). The list of 20 CMV strains from NCBI used for phylogenetic analysis is presented in Table 1. The phylogenetic analysis was conducted using MEGA version 5.2.1 software. A phylogenetic tree was constructed using the Neighborhood Joining method. The Kimura 2-parameter model was used to estimate the nucleotide distances among the compared sequences of the CP gene [13].

\section{Results and Discussion}

The symptomatic samples of vegetable plants were observed under field conditions in different locations. 126 plant samples belonging to the Cucurbitaceae and Solanaceae families were selected and tested for CMV. The plant samples were collected from following regions of Ukraine: Autonomic Republic of Crimea, Vinnytsia, Zaporizhzhia, Kyiv, Kirovohrad, Odessa, Poltava, Cherkasy and Chernihiv regions. The plants of Cucurbitaceae family 
(cucumber, squash, pumpkin, and zucchini) showed puckering, distortion, vein banding, yellowing, filamentary leaf structures, yellow leaf mosaics; dark green spots of different size, knobs and malformations on fruits. The plants of Solanaceae family (tomato, pepper, eggplant) showed disease symptoms in one month after seedtime during flowering. At first yellow spots and vein clearing have appeared on young leaves, followed by systemic yellow and green mosaics, chloroses and necroses. DAS-ELISA was performed for detection of viral antigens in plant samples. 38 of 126 plant samples were found CMVpositive. Virus-infected plants were detected in agriecosystems of Vinnytsia, Zaporizhzhia, Kyiv, Odessa, Poltava and Cherkasy regions.

For further investigations, two samples were chosen since they showed a high virus titer in DAS-ELISA and exclusive occurrence of CMV (among the range of viruses tested). The tomato (Lycopersicon esculentum) from Poltava region showed yellow spotting on fruits and leaf rolling. Such manifestation is considered classical symptoms of CMV with low rate of occurrence in Ukraine (Fig. 1). The source of another isolate was squash (Cucurbita pepo) from Poltava region with dark green mosaic along the leaf veins (Fig. 1).

RT-PCR with the extracted total RNA resulted in amplification of a cDNA (expected 500 bp long) covering a part of $\mathrm{CP}$ gene. The partial $\mathrm{CP}$ gene nucleotide sequences of Ukrainian CMV isolates were obtained.

A phylogenetic tree was constructed using aligned nucleotide sequences of the partial $\mathrm{CP}$ gene of various CMV strains isolated from different countries. The Phylogenetic analysis indicated three distinct clusters corresponding to subgroups IA, IB and II (Fig. 2).

Table 1. Strains of Cucumber mosaic virus used for phylogenetic analysis in this work

\begin{tabular}{|c|c|c|c|c|c|c|}
\hline \multirow{2}{*}{ Strain } & \multirow{2}{*}{$\begin{array}{l}\text { Sub } \\
\text { group }\end{array}$} & \multirow{2}{*}{ Host } & \multirow{2}{*}{ Origin } & \multirow{2}{*}{$\begin{array}{c}\text { Accession } \\
\text { number }\end{array}$} & \multicolumn{2}{|c|}{ Nucleotide homology } \\
\hline & & & & & Ukr-sq13 & Ukr-tom2 \\
\hline 237 & IA & Cucumis melo & Australia & AJ585518 & $94 \%$ & $94 \%$ \\
\hline $\mathrm{ABI}$ & IB & & Korea & L36525 & $98 \%$ & $98 \%$ \\
\hline ALS & II & $\begin{array}{l}\text { Host - Alstroemeria, lab host - } \\
\text { Nicotiana benthamiana }\end{array}$ & Netherlands & $\mathrm{AJ} 276587$ & $79 \%$ & $79 \%$ \\
\hline G10 & IB & Tobacco & Greece & AY541691 & $95 \%$ & $95 \%$ \\
\hline G2 & IB & Tobacco & Greece & AY450854 & $95 \%$ & $95 \%$ \\
\hline Hnt & II & Tobacco & China & KC407999 & $81 \%$ & $81 \%$ \\
\hline $\mathrm{I} 17 \mathrm{~F}$ & IA & & France & Y18137 & $94 \%$ & $94 \%$ \\
\hline $\mathrm{R}$ & II & & France & Y18138 & $82 \%$ & $82 \%$ \\
\hline $\mathrm{Rb}$ & IA & Rudbeckia hirta var. Pulcherrima & South Korea & GU327365 & $95 \%$ & $95 \%$ \\
\hline $\mathrm{S}$ & II & Lycopersicon esculentum & USA & AF172841 & $81 \%$ & $81 \%$ \\
\hline SD & IB & & China & AB008777 & $99 \%$ & $99 \%$ \\
\hline $\mathrm{TN}$ & II & $\begin{array}{l}\text { From tomato plants, lab host - } \\
\text { Nicotiana tabacum }\end{array}$ & Japan & AB176847 & $80 \%$ & $80 \%$ \\
\hline Twa & IA & Pepper & Ausralia & AJ585522 & $95 \%$ & $95 \%$ \\
\hline $\mathrm{V}$ & IA & Lab host - Nicotiana benthamiana & South Korea & AB369270 & $94 \%$ & $94 \%$ \\
\hline Vir & IB & Capsicum sp. & Italy & HE962480 & $95 \%$ & $95 \%$ \\
\hline $\mathrm{Z}$ & IA & Lab host-Nicotiana benthamiana & South Korea & AB369269 & $95 \%$ & $95 \%$ \\
\hline
\end{tabular}


The CMV strains belonging to subgroup II formed a different cluster on the phylogenetic tree, well separated from the members of subgroup I. Within subgroup I, Ukrainian CMV isolates showed close phylogenetic relationships rather with the members of subgroup IB than IA, which formed a separate cluster.

Ukrainian isolates shared 79-99 \% nucleotide homology with the strains reported from all over the world (Table 1). According to literature data, the members of the same group share more than $90 \%$ homology. The homology between strains from I and II subgroups was approximately 69-77\% [3]. The nucleotide sequences shared 92-94 \% similarity among IA and IB subgroup strains [14]. Ukrainian isolates were phylogenetically most related to each other and to the members of subgroup IB ( $>95 \%$ nucleotide homology). However, they were distinct from the subgroup IA and subgroup II strains. The members of subgroup II showed the lowest nucleotide homology (79-82 \%) with the Ukrainian isolates of CMV studied.

The phylogenetic analysis of partial sequences of the CP gene of Ukrainian isolates of CMV revealed the highest homology and close relationships with the strains ABI and SD from Korea and China. They shared approximately 98-99\% homology. The infrequent amino acid substitutions revealed a high similarity in this gene region. The protein sequence of ABI strain is different from those of Ukr-sq13, Ukr-tom2, and SD, and has two amino acid substitutions (YA IT corresponding to 601,602 positions). The sequence comparison of Ukrainian isolates showed their high similarity. Based on the results obtained, these Ukrainian isolates of CMV were identified to belong to the subgroup IB. The sequence data have been submitted to NCBI, accession numbers KJ921838 and KJ921837 for Ukr-tom 2 and Ukr-sq13 isolates, respectively.

\section{Conclusions}

The results obtained confirm the wide dissemination of CMV in Ukraine. The analysis of many samples collected from nine regions of Ukraine representing approximately $1 / 3$ of the country area suggests that about $30 \%$ of plants with manifested symptoms were CMV-positive. Despite the supposed high rate of CMV evolution and adaptation [2], the phyloge- netic analysis of two Ukrainian isolates of CMV reveals that their homology exceeds $95 \%$, i.e. that these isolates belong to the same strain. In our opinion, it is of special interest as these isolates have been found in totally different host plants, tomato and squash, which belong to distant families.

Another important phylogenetic finding is that Ukrainian isolates of CMV are attributed to the subgroup IB of CMV strains. The Ukrainian isolates are mostly related to the strains ABI and SD from Korea and China, respectively. Initially, the members of subgroup IB were found in (and thought to be restricted to) the East Asia. Later on, the subgroup IB strains of CMV were shown to be widespread in Iran [1], however the subgroup IA isolates were also detected [15]. The occurrence of subgroup IB isolates of CMV suggests that they might have been introduced in Ukraine either by seed material or through the exported fresh food products. Additionally, we cannot reject a possibility of the virus 'natural migration' from Iran (or other neighboring regions) to Ukraine by aphid or birds.

Strangely, we have not found the subgroup IA isolates of CMV in Ukraine as yet. These are more virulent strains and isolates which are considered to be common worldwide, including Europe. In accordance with Zitikaite I, et al. [10], the CMV subgroup II was detected in pumpkins from Ternopol and Chernivtsi regions of Ukraine. Thus, based on previous research data and our findings, the CMV population in Ukraine consists of the isolates of II and IB subgroups. Having registered severe symptoms on collected plants, we expected that they were induced by a virulent 'form' of the virus. Surprisingly, both isolates fall into the subgroup IB strains of CMV. In the view of aforesaid, we deem that the obtained results rather reflect the lack of CMV monitoring in Ukraine than reveal atypical virus spread in the region.

The data also indicate that the severity of the virus-specific symptoms in field conditions may not be directly related to the degree of virulence of a given virus isolate, requiring more research on the CMV biology, epidemiology and evolution.

\section{Acknowledgements}

The authors are grateful to Dr. I. I. Boubriak for his invaluable support and technical assistance. 


\section{REFERENCES}

1. Arafati N, Farzadfar S, Pourrahim R. Characterization of coat protein gene of Cucumber mosaic virus isolates in Iran. Iran J Biotech. 2013;11(2):109-14.

2. Roossinck MJ. Evolutionary history of Cucumber mosaic virus deduced by phylogenetic analyses. J Virol. 2002;76 (7):3382-7.

3. Palukaitis P, Garcia-Arenal F. Cucumoviruses. Adv Virus Res. 2003;62:241-323.

4. Brigneti G, Voinnet O, Li WX, Ji LH, Ding SW, Baulcombe DC. Viral pathogenicity determinants are suppressors of transgene silencing in Nicotiana benthamiana. EMBO J. 1998; 17 (22):6739-46.

5. Ng JC, Perry KL. Transmission of plant viruses by aphid vectors. Mol Plant Pathol. 2004;5(5):505-11.

6. Suzuki M, Kuwata S, Masuta C, Takanami Y. Point mutations in the coat protein of cucumber mosaic virus affect symptom expression and virion accumulation in tobacco. $J$ Gen Virol. 1995;76 (Pt 7):1791-9.

7. Palukaitis P, Roossinck MJ, Dietzgen RG, Francki RI. Cucumber mosaic virus. Adv Virus Res. 1992;41:281-348.

8. Roossinck MJ, Zhang L, Hellwald KH. Rearrangements in the 5' nontranslated region and phylogenetic analyses of cucumber mosaic virus RNA 3 indicate radial evolution of three subgroups. J Virol. 1999;73(8):6752-8.

9. Sclavounos AP, Voloudakis AE, Arabatzis Ch, Kyriakopoulou $P E$. A severe hellenic CMV tomato isolate: symptom variability in tobacco, characterization and discrimination of variants. Eur J Plant Pathol. 2006; 115(2): 163-72.

10. Zitikaitè I, Staniulis J, Urbanavičiene L, Žižytè M. Cucumber mosaic virus identification in pumpkin plants. Žemdirbystè. 2011; 98(4):421-6.

11. Crowther JR. ELISA. Theory and practice. Methods Mol Biol. 1995;42:1-218.

12. Bariana HS, Shannon AL, Chu PW, Waterhouse PM. Detection of five seedborne legume viruses in one sensitive multiplex polymerase chain reaction test. Phytopathology. 1994; 84(10): 1201-5.

13. Kimura $M$. A simple method for estimating evolutionary rates of base substitutions through comparative studies of nucleotide sequences. J Mol Evol. 1980; 16(2):111-20.

14. Kumari R, Bhardwaj P, Singh L, Zaidi AA, Hallan V. Biological and molecular characterization of Cucumber mosaic virus subgroup II isolate causing severe mosaic in Cucumber. Indian J Virol. 2013;24(1):27-34.

15. Nematollahi S, Sokhandan-Bashir N, Rakhshandehroo F, Zamanizadeh HR. Phylogenetic analysis of new isolates of Cucumber mosaic virus from Iran on the basis of different genomic regions. Plant Pathol J. 2012; 28(4): 381-9.

Т. П. Шевченко, О. В. Тимчишин, Е. Аль Далаін,

А. С. Бисов, І. Г. Будзанівська, О. В. Шевченко, В. П. Поліщук

Перше повідомлення про детекцію ізолятів підгрупи IB вірусу огіркової мозаїки в Україні

Мета. Встановлення штамової приналежності українських ізолятів вірусу огіркової мозаїки (ВОМ) на основі філогенетичного аналізу фрагмента послідовності гена капсидного білка. Ме- тоди. Імуноферментний аналіз (ІФА), полімеразна ланцюгова реакція зі зворотною транскрипцією (ЗТ-ПЛР), сиквенування ДНК та філогенетичний аналіз. Результати. ВОМ є широко розповсюдженим патогеном сільськогосподарських культур в Україні. Були відібрані й проаналізовані зразки рослин з вірусоподібними симптомами представників родин Cucurbitaceae $i$ Solanaceae. Виходячи з результатів візуальної та серологічної діагностики, два зразки Lycopersicon esculentum i Cucurbita pepo з Полтавської області були обрані для подальших молекулярних досліджень. Були ампліфіковані й сиквеновані часткові послідовності гена капсидного білка. Отримані послідовності кДНК гена капсидного білка цих ізолятів порівняли з опублікованими в Генбанку послідовностями штамів ВОМ різних підгруп. Найбільша гомологія українських ізолятів продемонстрована зі штамами ВОМ підгрупи IB. Найбільш спорідненими до українських ізолятів виявилися штам ABI з Кореї та штам SD 3 Китаю. Висновки. Спираючись на результати філогенетичного аналізу, можна стверджувати, що детектовані українські ізоляти вірусу огіркової мозаїки належать до групи IB. Наші результати $€$ першим повідомленням про наявність ізолятів ВОМ підгрупи IB на території України.

Кл юч о в і с л о в а: Вірус огіркової мозаїки, ген капсидного білку, філогенетичний аналіз.

Т. П. Шевченко, О. В. Тымчишин, Е. Аль Далаин, А. С. Бысов, И. Г. Будзанивская, А. В. Шевченко, В. П. Полищук

Первое сообщение о детекции изолятов подгруппы IB вируса мозаики огурца в Украине

Цель. Установить штаммовую принадлежности украинских изолятов вируса мозаики огурца (BMO) на основании филогенетичного анализа частичной последовательности гена капсидного белка. Методы. Иммуноферментный анализ (ИФА), полимеразная цепная реакция с обратной транскрипцией (ОТ-ПЦР), секвенирование ДНК и филогенетический анализ. Результаты. ВМО широко распространён в Украине среди сельскохозяйственных культур. Были отобраны и проанализированы образцы растений с вирусоподобными симптомами семейств Cucurbitaceae и Solanaceae. На основе визуальной и серологической диагностики два образца Lycopersicon esculentum и Cucurbita реро из Полтавской области были избраны для дальнейших молекулярных исследований. Были амплифицированы и секвенированы частичные последовательности гена капсидного белка. Проведено сравнение полученных последовательностей кДНК гена капсидного белка этих изолятов с опубликованными в Генбанке последовательностями штаммов ВМО различных подгрупп. Наибольшая гомология украинских изолятов продемонстрирована с представителями подгруппы IB. Наиболее родственными к украинским изолятам показаны штаммы ABI (Корея) и SD (Китай). Выводы. Исходя из результатов филогенетического анализа, украинские изоляты ВОМ принадлежат к подгруппе IB. Результаты этой работы являются первым свидетельством присутствия изолятов подгруппы IB BMO на территории Украины.

Ключе вы е сл ова: вирус мозаики огурца, ген капсидного белка, филогенетический анализ.

Received 24.12.2014 